\title{
Clonal colony in the Early Devonian cnidarian Sphenothallus from Brazil
}

Heyo Van Iten, Juliana De Moraes Leme, Marcello G. Simões, and Mario Cournoyer Acta Palaeontologica Polonica 64 (2), 2019: 409-416 doi:https://doi.org/10.4202/app.00576.2018

The fossil record of polypoid cnidarians includes a number of taxa that were incorrectly identified as either tubiculous worms or plants. The holotype of the putative alga Euzebiola clarkei (Ponta Grossa Formation, Lower Devonian, Brazil), originally described under the name Serpulites sica , is re-described and re-figured as a species of Sphenothallus, a medusozoan cnidarian. Unlike Sphenothallus from other localities, the black, organic-walled Ponta Grossa specimen consists of a single parent tube that is confluent with the apical ends of at least 18 daughter tubes. The pattern of arrangement of the daughter tubes, which are arrayed in single file along the exposed face and the two thickened margins of the parent tube, partly resembles the whorl-like pattern of arrangement of colonial polyps of certain scyphozoan cnidarians. For these reasons, the Ponta Grossa Formation material figures prominently in the argument that Sphenothallus was a medusozoan cnidarian capable (in at least one species) of clonal budding.

Key words: Cnidaria, Medusozoa, Scyphozoa, Hydrozoa, clonal budding, Devonian, Brazil.

Heyo Van Iten [vaniten@hanover.edu], Department of Geology, Hanover College, Hanover, IN 47243, USA and Research Associate, Cincinnati Museum Center, Department of Invertebrate Paleontology, 1301 Western Avenue, Cincinnati, OH 45203, USA. Juliana de Moraes Leme [jleme.usp@gmail.com ], Department of Sedimentary and Environmental Geology, University of São Paulo, 05508-080, SP, Brazil. Marcello G. Simões [profmgsimoes@ gmail.com ], Department of Zoology, São Paulo State University, Botucatu campus, 18618-689, Botucatu, SP, Brazil. Mario Cournoyer [paleovision@videotron.ca], Musée de Paléontologie et de l'Évolution, 541 Congrégation Street, Montréal, Québec, Canada H3K 2J1.

This is an open-access article distributed under the terms of the Creative Commons Attribution License (for details please see creativecommons.org), which permits unrestricted use, distribution, and reproduction in any medium, provided the original author and source are credited. 
FoF Full text $(662.2 \mathrm{kB})$ 